\title{
Building Social Capital Through Rhetoric and Public Relations
}

Management Communication Quarterly 25(3) 436-454

(C) The Author(s) 2011 Reprints and permission: http://www. sagepub.com/journalsPermissions.nav DOI: $10.1 \mid 77 / 08933$ |89||410286 http://mcq.sagepub.com

@SAGE

\section{Maureen Taylor'}

\begin{abstract}
When the focus is on meaning making, language, rhetorical argument, and persuasion, there is enormous potential to see how public relations theory and practice in external organizational rhetoric can serve community interests - or not. Rhetoric (as the discourse) and public relations (as the enactment of that discourse) are essential to building and sustaining a society as a good place to live because they create various types of social capital. This article describes the various relationships among international and indigenous NGOs, business organizations, and community activists in facilitating (and, at times, frustrating) dialogue in Jordan. It offers an example of how social capital may be created when rhetors using public relations advocate in ways that enhance the capacity of local governance and make their community a better place to live.
\end{abstract}

\section{Keywords}

civil society, participation, organizational capacity, development

Contemporary life is shaped by multiple and often competing discourses, but citizens are not passive receivers of messages. Rather, citizens can shape societal discourses through their private and public agency. Through discourse, humans develop the images in their minds that allow them to learn

'University of Oklahoma, Norman

\section{Corresponding Author:}

Maureen Taylor, University of Oklahoma, Norman, OK

Email: mtaylor@ou.edu 
about, evaluate, and advocate about issues. Without multiple and competing discourses, humans, as members of society, would not have the building blocks for making decisions. Images are an important part of making enlightened choice. Kenneth Boulding (1977) observed that humans have perceptions of themselves that are rooted in space and time. These images exist "in a field of personal relations" (pp. 4-5). Our knowledge, our individual perceptions, or what we "believe to be true," is called our "image" of the world (p. 6). Personal, organizational, political, and social behavior are all based on images. These images are created by, changed, and reinforced by the meanings of discourses - and in this process organizations (private and public) facilitate and confound the efforts to use dialogue to achieve shared images.

Boulding's conceptualization of image and knowledge is relevant to this article (and to this special issue of Management Communication Quarterly) because his work is foundational for understanding how organizational rhetoric through public relations can work to make society a better place for people to live. By this logic, however, we acknowledge that such efforts can also be frustrated by dysfunctional and self-interested rhetorical initiatives. As the other articles in this special issue illustrate, rhetoric through public relations provides the discourses that construct issues and their resolutions. The media (print, electronic, digital, and social) extend rhetorical and public relations efforts by holding up the arguments and actions of organizational rhetors to public scrutiny. Rhetoric (as the discourse) and public relations (as the enactment of that discourse) are as essential to sustaining a society as a good place to live as oxygen is essential to sustaining human life. This is so because rhetoric and public relations can create various types of social capital needed to build or to sustain a community or society.

Heath's introduction to this special issue positions rhetoric as "relevant to any context in which humans are compelled to make enlightened choice" (p. 7). Individuals and organizations become rhetors when they seek to communicate their agendas. Public relations extends this organizational rhetoric and allows these agendas to be enacted. The public discussion of agendas allows for what Heath and others have called enlightened choice. The thesis of this article is that enlightened choice that comes from rhetoric and public relations. Together, they foster social capital that societies need.

To understand individual agency, organizational agendas, and enlightened choice, the first part of the article explores organizational rhetoric through public relations. This section attempts to answer the question of this special issue: What makes a society a good place to live? The answer is dependent on a variety of cultural, social, economic, and political processes needed to create social capital to form what Heath (2006) has called "a fully functioning society" (p. 96). 
To show how various processes and relationships contribute to a fully functioning society, the second section of the article examines the case of how individuals and organizations in one Jordanian town are working to make their community a better place to live. They are using rhetoric and public relationsfacilitated communication to learn about each other and adjust to a changing environment. The community is still evolving, and its end state is not certain. The case study shows how even simple communication and coordination tasks that create social capital can be difficult to accomplish. Yet, this case study offers an example of how social capital may be created through organizational rhetoric communicated through public relations to advocate issues positions needed for relationship building and other enlightened choices.

\section{Reconsidering Public Relations, Rhetoric, and Social Capital}

Public relations scholars have long argued that public relations can (in fact must) help to improve communities. Some have advocated a communitarianism approach to public relations (Leeper, 1986, 2000). Drawing on the Chicago School, Kruckeberg and Stark (1988) argued that organizations have a role to play in their community and that organizational interests are best served when community interests are served. These early societal-level approaches to public relations provide a key foundation for today's theorizing about public relations.

Heath (2006) recently built upon this early work to argue that public relations can add value to community if it helps foster a fully functioning society. Heath identified eight premises that articulate a societal role for organizational rhetoric and public relations in making a community a better place to live. Heath's premises can be summarized as follows: (a) Management works to bring order to uncertainty, (b) corporate responsibility, (c) power resource management, (d) community as conflicting and conjoined interests and expectations, (e) relationship as symmetry: communitas versus corporatas, (f) organizational communication, (g) responsible advocacy, and (h) narrative and other forms of rhetoric leading to enlightened choice (pp. 99-110).

The first premise explains how organizations should act if they want to be valued partners in making a society more fully functioning. Organizations, especially the leaders of organizations, should help make decisions that bring order and control to uncertainty. Decisions that benefit society ultimately benefit the organization. Public relations research such as environmental scanning can help to inform and influence organizational leaders' decisions on such challenges. 
Organizations are not autonomous. The public and the political systems that represent the public interest have the ability (though not always the will) to exert significant influence over organizations. Fully functioning society theory (FFST) reminds us that an organization's legitimacy is tied to its capacity to meet or exceed the normative expectations of stakeholders. When organizations violate the expectations of the community, they lose legitimacy. The public (and policy makers) are more likely at this time to scrutinize previously unscrutinized actions of the organization.

Heath's second and third premises suggest that society is best served when organizations use their power responsibly. Some organizations have greater symbolic and capital resources than others. An organization with access to power, including that achieved through the media, should not use these relationships self-interestedly to the detriment of society, and if they do, then these organizations should expect challenges from other community actors (rhetors). For instance, corporations have the ability to hire lobbyists and media relations experts. Although activist groups may not have such tangible resources, they have rhetorical options and public relations strategies at their disposal as citizens. The value of rhetoric, whether by businesses and government or activist publics, is that it is one resource that helps to level the playing field between those organizations with tangible resources and those without tangible resources.

FFST's fourth premise postulates that all people and organizations work to maximize their self-interest. An organization's interests are served when it attempts to coordinate and manage its own and the community's interests at risk. Enlightened choice occurs when different societal actors use rhetoric to share and contest information, publicly acknowledge and champion their interests, and show explicitly the intersection of their interests with those of others in the community. Thus, the fifth premise of FFST teases out the communitas-corporatas distinction advocating for open, two-way communication (dialogue) among parties based on trust and cooperation (a spirit of collaboration). Heath argues that aligned interests among groups are best for the functioning of society. Boyd and Stahley (2008) recently took the communitas-corporatas distinction further by identifying the inherent tensions of organizational actors seeking to balance these competing rhetorics. Boyd and Stahley's examples, though taken from sports discourse, very much apply to organizational competition and cooperation.

The aforementioned five premises of FFST are based on an organization's orientation to the community and an organization's recognition of how it is linked to the community. This orientation is the first step, but an organization must have the internal capacity to follow through on the commitments implicit 
in this orientation. Three additional FFST premises form the foundation for the remainder of this article and suggest ways that organizations can develop the processes and structures necessary to enact this orientation to the community. Heath's sixth premise argues that organizations need to have internal communication processes that allow for coordination of external efforts. Organizations need to be open to and capable of responding to the needs of stakeholders. How does this happen? The seventh premise provides the tools for the advocacy of individuals, groups, and organizations in a fully functioning society. For Heath, enlightened choice comes from the wrangle (advocacy and counter advocacy_-statement and counter statement) of ideas. People make decisions based on the discourses that create, define, and resolve issues. Without the advocacy of the societal actors, others would not be able to have the information, evaluations, identifications, and policy positions they need to make enlightened choices. Heath's concluding premise identifies organizational rhetoric through public relations as essential for a fully functioning society.

FFST theory identifies the premises of how rhetoric and public relations can help to make society a better place to live. Heath's vision of a fully functioning society makes an implicit claim that the relationships among organizations and groups create a social capital that makes the community stronger and better able to meet the needs of its members. The social capital is an outcome of organizational orientations, organizational capacity to respond to positions advocated by publics, and the collective advocacy (through rhetoric and public relations) of different actors to advance choice to the benefit of the community. Public relations is the enactment of organizational rhetoric, and together they help to create organizational and social capital.

\section{Building Organizational and Community Social Capital}

Social capital is an emerging concept across a variety of disciplines. Nahapiet and Ghoshal (1998) determined that the concept first emerged in community/ neighborhood studies in the late 1960s. For instance, many of us know Granovetter's (1973) research on the strength of weak ties and the implications of weak ties on the survival of neighborhoods experiencing difficult transitions. By the mid-1980s, social capital emerged as a sociological concept that sought to explain the relationships that form the foundation for each society (Bourdieu, 1986; Coleman, 1988).

Management and organizational communication scholars, especially those who study networks, have explored the social capital created by relationships 
among firms and not-for-profit organizations. Lewis (2005) challenged organizational communication scholars to study topics, including social capital, to show how organizations must contribute to society.

What we may have overlooked, in such work, is the notion of community in a larger sense (e.g., locality, region, city, town, neighborhood) and how organizations are integral to building social capital. How do organizations enable, ignite, and provide conduits for social capital within a community? (p. 246)

Whereas Lewis and others have noted that social capital has been studied from many different perspectives, Kennan and Hazelton (2006) cautioned that the clarity of the concept of social capital is still marked by "gaps in treatment, method, and theoretical development" (p. 321). Kennan and Hazelton outlined the theoretical origins and relational as well as communication dimensions of social capital and tie them to the internal public relations function in organizations. They also discuss the consequences of social capital (both positive and negative), arguing that social capital theory places the function of public relations in a key position for organizations. Kennan and Hazelton approached social capital from an organizational-centric position with the benefits of social capital helping to make an organization more competitive and successful. Social capital is also a valuable theoretical lens for understanding how relationships, information sharing, coordinated activities, and cooperation can help societies successfully manage risk and create greater opportunities and efficacy for members (Ihlen, 2007).

Taylor (2009) extended the discussion of social capital by examining how different types of organizations can and must participate in society. She defined civil society as "the process of interactions that lead to relationships, build trust and create social capital" (p. 77). Civil society is not an end state, but instead it is a "process grounded in rhetoric" (p. 83). Civil society "is a socially constructed process that can be created, maintained, and changed by rhetorical public relations activities" (p. 77). Taylor identified seven organizational partners that create the building blocks of civil society: (1) the public; (2) societal institutions (such as religious organizations, professional groups, universities, unions, and political parties); (3) the media; (4) NGOs and social cause groups; (5) the business community; (6) governance-the local, regional, and national leaders that participate in policy formation; and (7) international organizations.

Although each partner has its own issues and needs and will represent different citizen interests, it is the goal of civil society to have interrelated 
objectives and convergent interests among these different groups. When the rhetorical discourse of two or more partners converge, then there is a much greater opportunity for the community collectively to make enlightened choice. An effective civil society rests in the intersection of all of these partners' interests. At this intersection of interests the role for organizational rhetoric becomes most clear. The question then is how does this intersection of interests occur? How do rhetoric and public relations facilitate the intersection of interests? The next section provides an answer to this question.

\section{Public Relations Facilitates Internal and External Dialogue}

Organizations and engaged groups use rhetoric and public relations to build the social capital that make communities and society a better place to live. But the desire to participate in the "wrangle of the marketplace" of ideas and interests does not always mean that the organization has the capacity to do so (Heath, 1992). Many organizations have structural and communication impediments that diminish their capacity to participate in creating social capital. They are too selfish, too afraid, too preoccupied with short-term objectives, have a weak public relations function, or may even lack the internal communication processes for figuring out how to participate in their communities.

These obstacles can be minimized if the organization looks inward first. Ron Pearson (1989) suggested that organizations could engage in ethical public relations and relationship building if they have dialogic "systems rather than monologic" policies. In other words, Pearson recognized that internal organizational processes and rhetoric such as good environmental scanning, a culture that fosters mutually beneficial relationships with public, and an orientation about being a member of the community are prerequisites for an organization to be able to ethically participate in society. Kent and Taylor (2002) advanced Pearson's work on dialogue as a practical way that organizations should engage their publics. They conducted an extensive literature review of the concept of dialogue in communication, public relations, philosophy, and psychology to identify five overarching tenets of dialogue, including mutuality, or the recognition of organization-public relationships; propinquity, or the temporality and spontaneity of interactions with publics; empathy, or the supportiveness and confirmation of public goals and interests; risk, or the willingness to interact with individuals and publics on their own terms and in ways that suffer the uncertainty or risk of such engagement; and finally, commitment, or the extent to which an organization gives itself over to dialogue, interpretation, and understanding in its interactions with 
publics. Dialogue, as an orientation, is essential to a fully functioning society. It is the foundation of social capital because it gives organizations the initial orientation and subsequent internal capacity through which to engage and adapt to the community.

The previous parts of this article responded to the question: How can rhetoric and public relations help to make society a better place to live? The answer may appear simple: Organizations and engaged groups use rhetoric and public relations to build the social capital that make communities and society a better place to live. Yet the reality of using rhetoric and public relations to make communities a better place to live is fraught with challenges, obstacles, and uncertainty. The next section provides a case study describing how the rhetoric, public relations, and relationship-building efforts of different civil society partners intersect to make a small town in Jordan a better place to live. The community of focus for this case study is the town of Aqaba in southern Jordan. It is on the "fast track" for economic development, but most other parts of the community (city services, education, sanitation, transportation) are not keeping pace with the accelerated economic growth. This case study provides insight into the potential of creating social capital and the obstacles inherent in building a fully functioning society in a community in transition.

\section{Creating Dialogue in the Desert: Making Aqaba, Jordan, a Better Place to Live}

The country of Jordan is located in a tough geographic neighborhood sharing borders with Israel, Syria, Saudi Arabia, and Iraq. Jordan lacks the oil resources that many of its neighbors enjoy. King Hussein ruled Jordan for nearly 47 years and in that time he carefully cultivated relationships with all of Jordan's neighbors. King Hussein presided over a large government sector in Jordan. The government owned most of the country's assets, including the airline, port, and natural resources. The government was the largest employer in the nation, and many Jordanians viewed government employment as an ideal job. The "cradle to grave" government support was unsustainable, but it was difficult for the king to take away the safety net.

In 1999, King Hussein died from non-Hodgkin's lymphoma cancer. His oldest son Abdullah II became King of the Hashemite Kingdom of Jordan. King Abdullah has attempted to do what his father could not: wean the Jordanian people from the system of government support. The new monarch increased foreign investment, built relationships among the public and private sector, and created a group of Free Trade Areas in the country to stimulate private sector development. The Aqaba Free Trade Zone was one of these 
areas. Aqaba was probably best known to tourists as a fishing village that serves as the gateway to Petra (a world heritage site featuring Nabataean ruins) and the Wadi Rum desert. The history of Aqaba, at the southern most tip of Jordan, dates back to the Ayla settlement and trading post (4000 BCE). The population of Aqaba has grown from 50,000 in 1980 to more than 100,000 in 2009. Most of this growth is attributed to people moving to Aqaba in the last decade to participate in its economic growth. Aqaba looks nothing like it did in the past. The government sold the beach property, and now the coast is filled with five-star hotels. A new modern seaport is underway, and there is significant real estate development catering to wealthy families from across the Middle East and North Africa (MENA).

When King Abdullah created the Aqaba Special Economic Zone (ASEZ), he also made a controversial decision to place a government bureaucracy in charge of governing the zone. Instead of Aqaba having an elected governor or other types of elected officials, Law No. 32, 2000, ruled that the ASEZ is supervised by a chief commissioner appointed by the king (with approval by parliament). The residents of Aqaba have no directly elected leaders and, thus, have minimal formal mechanisms to influence the governing body - the Aqaba Special Economic Zone Authority (ASEZA). The lack of democratic processes, however, did not diminish external stakeholders' interests in having citizens provide input into the ASEZA.

\section{Donors Push Economic and Democratic Reforms in Jordan}

King Abdullah recognized that Jordan would benefit from both resources and expertise from the West to build the infrastructure needed to make Jordan a good place to live. King Abdullah sought out and won international support for private sector development in Jordan. Taylor (2009) identified international donors as playing roles in civil society in postcrisis or transitional nations. The Jordan example shows the role that international trade organizations such as the World Trade Organization, World Bank, and other bilateral/ multilateral trade agreements also play in shaping events and relationships in developing nations.

Jordan had to make significant changes to existing government policies as it sought out private investment and international donor support for its development. The U.S. government also created a generous aid package for Jordan. The United States Agency for International Development (USAID) developed a multiyear program, Aqaba Zone Economic Mobilization (AZEM), to build the capacity of the governing bureaucracy of the ASEZA. The mobilization 
effort was tasked with improving the internal management of the authority so that it could better fulfill its mission to "improve the quality of life for all community members" (Kardoosh, 2005, p. 3). At the same time, the AZEM program sought to build up the capacity of the people in the Aqaba community to engage and maintain accountability of the ASEZA. The AZEM program supported the formation of grassroots groups of citizens at the neighborhood level.

The European Union also created a multiyear program of assistance to Aqaba to ensure that the organization functioned appropriately and that the community had some capacity to engage ASEZA. Al-Anis (2007) noted, "Dialogue between NGOs, local businesses, community and interest groups, and the zone authorities is seen [by donors] as very important and useful for the success of the overall ASEZ model" (p. 4). The EU's engagement with Jordan is perceived to be a mechanism "that invigorates dialogue and provides at the very least a forum" for discussions amongst local, national, and international parities interested in Aqaba's economic and political development (p. 4). American and European engagement promotes "social, political and economic reform processes in the Kingdom" (p. 5). External stakeholders, now with an economic interest in Jordan, are watching how the ASEZA is serving citizens.

\section{The Government of Jordan Holds ASEZA Accountable}

The Port of Aqaba project is a centerpiece in Jordan's program for economic growth. The port has seen good times and bad times. For many years (up to and including the first Gulf War), the port of Aqaba served as an outlet for Iraqi oil and goods. It was one of Iraq's only outlets during the Iraq-Iran war and during United Nations' sanctions (1991-2003). Talal (2004) noted that the embargo against Iraq created a de facto embargo against Jordan. Sanctions against Iraq (1991-2003) may have cost Jordan more than a billion dollars of revenue each year.

The legislative branch of the Jordanian government provides oversight of ASEZA. Although the Jordanian Parliament is rarely conceived of as a prodemocratic, reform-minded body, the parliament is acutely aware that ASEZA must be an effective administrative organization (Kardoosh, 2005). As early as 2001, members of the legislative branch began raising concerns about ASEZA's capacity to serve the needs of the residents in Aqaba. To create oversight, they passed laws to ensure that ASEZA officials could not have an economic interest or commercial ties with investors. Members of parliament also questioned high salaries and demanded that ASEZA hire 
employees from the local Aqaba community. The parliament created laws to force ASEZA to have some type of accountability to the people, the businesses, and the investors in the zone.

\section{Business Community Needs ASEZA to Improve Services}

The zone was created to enhance economic development in southern Jordan. Most development projects had been centered in the greater Amman area and served a largely urban public. When young people graduated from southern high schools or universities, they often moved to the capitol. The governorates in the south and in the north had minimal strategic development initiatives, and the residents had little access to economic opportunity. The ASEZ was created to bring jobs and opportunities for people in the south so that communities would be able to keep their cultural and human capital.

Jobs in Aqaba are actually not tied directly to the port relocation and modernization. Ironically, as the port becomes modernized, it will require fewer workers. The current port has approximately 3,000 government employees who enjoy all of the benefits of public sector employment (housing, health, and pensions). The number of people required to run the new port will be significantly lower, and many workers will need to find new jobs. The local, national, and international business community is expected to hire the surplus workers from the port relocation project. This may not be as easy as it seems. There is disconnect between the jobs that are created today and the jobs that people in Aqaba want to pursue. The town of Aqaba is awash in construction projects. There is construction for new hotels, new housing developments (some with villas that cost millions of dollars), shopping centers, schools, hospitals, and infrastructure construction. Yet the local community has not yet shown any interest in pursuing this work. Egyptians and South Asians have been brought in to provide the manual labor required on the construction projects. Hotels have had to import workers from Indonesia, Bangladesh, and the Philippines to meet unskilled labor needs (housekeeping, food service). It appears that local residents of Aqaba are unwilling to work in either the hospitality sector or the construction sector. These are not the types of jobs that residents want, yet many are not qualified for higher-paying and more prestigious jobs.

Although the economic promise of the ASEZ remains unfulfilled for the local residents of Aqaba, the need for local expertise is quite high. Large construction and hospitality projects require local businesses to supply them with local goods and expertise. Hotels need dry cleaners, florists, plumbers, 
electricians, and skilled maintenance teams. There is limited capacity in locally owned businesses to meet this need. Thus, the major employers in Aqaba are procuring services from Amman. Many Amman-based companies have tried to expand to Aqaba and grow their businesses in the zone. They have had varying levels of success in acquiring the permits needed to operate. ASEZA struggles to provide regulatory services to these organizations that would allow them to operate legally. ASEZA is charged with facilitating business development, but there is disconnect between the authority's mission and its capacity to actually facilitate business start-ups in the zone.

What is happening in Jordan is not uncommon. Many government bureaucracies across the world lack the capacity simultaneously to develop and regulate businesses. In Jordan, national NGOs have attempted to fill the gap by helping to jump start small businesses and train citizens.

\section{Building Up NGOs Creates Accountability and Social Capital in Aqaba}

A variety of Jordanian and international organizations fund community and economic development projects in Aqaba. The Queen Noor Foundation, led by King Hussein's widow, seeks to empower Jordanian women. The Jordan River Foundation (JRF), chaired by the new queen, Rania Al-Abdullah, is a nonprofit Jordanian NGO that also seeks to empower Jordanians. A report by Foundation for Cooperative Housing (FCH) found mixed results of these efforts "as the lack of a community development strategy through which resources could be channeled have led to a fractured and incomplete set of interventions and no ability to measure the impact of those interventions" (p. 4).

The donor community and national NGOs have been working to build neighborhood capacity in Aqaba. Grassroots groups, called Neighborhood Enhancement Teams (NETs), are being created to represent the interests of the different neighborhoods. The goal of these teams is to gather input from the neighborhood and present neighborhood needs to ASEZA. The NETs also have a role in monitoring ASEZA progress toward resolving the community needs. The NETs are responsible for monitoring the progress because there is no local watchdog media in Aqaba.

\section{A Fully Functioning Society Needs Media}

Taylor (2009) identified media as a key actor in building civil society. Media serve as an infrastructure through which organizational rhetoric is extended 
through public relations so that multiple discourses can be shared. The creation of social capital is limited in Aqaba because there is no local media outlet. ASEZA needs to communicate with the public, the business community, and its 3,000 employees. Since it essentially plays the role of municipal government, it needs to communicate rhetorically to its constituents about key topics. It also needs to make sure that employees know about changes in the regulations for home construction permits, business construction permits, and so on. As well as providing information, the organizational rhetoric needs to engage in dialogue with key interests' understanding, preferences, and identifications.

There is currently no daily newspaper or Aqaba-focused radio station in the zone. The residents of Aqaba get their news and information from regional radio and national television (JTV is owned by the Jordanian government). There are two weekly news magazines that specialize in advertisements, and they sometimes carry news about the community. The lack of local media is a major problem for ASEZA's engagement with the public. The organization has tried to create new tactics. It has published a monthly magazine to communicate with the public, hosts a website, and posts banners across Aqaba to announce social and cultural events. But the people of Aqaba live in an information-poor environment where rumor and personal connections provide the information for decision making. ASEZA's weakness means that residents do not have the basic information and evaluations required for enlightened choice. And ASEZA has few structured means to listen to key factions' preferences.

\section{Weak Internal Capacity Creates Weak ASEZA Response to Community Needs}

The weak internal capacity of ASEZA plays a key role in its weak external relationships with stakeholders. Currently, there are very few ways that ASEZA can generate dialogue in a systematic way from the public. ASEZA does have a unit entitled Local Community Development Division and a small media relations office. However, both units have yet to prove their effectiveness in engaging in dialogic communication with the public. Time is running out for ASEZA to be prepared to meet public needs. The citizens are becoming more organized and vocal about their needs in Aqaba. Counter statements are forming but without useful venues that can eventually lead to collaboration. Far too long has governmental rhetoric been monologic. Now ASEZA struggles to be dialogic, and its capacity to be so is unclear. 


\section{The Beginnings of Dialogue in the Desert}

Citizens in Aqaba have had no history of participation in decision making. According to Talal (2004), one of the greatest contributions of Jordanian NGO development was the participatory dimension that allowed citizens, especially the poor, to gain new information and resources that would have an immediate impact on their lives. In Aqaba, the Neighborhood Enhancement Teams (NETs) were created as public relations structures to represent the interests of the different neighborhoods. They advocated for increased responsiveness by ASEZA to community needs. Neighborhood activists, working with the JRF or $\mathrm{CFH}$, have been trained to organize neighborhood meetings. The goal of these meetings is to develop mechanisms for individual participation in community decision making. The meetings and the relationships created at these meetings create social capital. The following section is a description of how rhetoric, public relations, and the components of a fully functioning society are being played out in Aqaba. The case study is based on the author's observations and participation working on media and civil society projects in Jordan during the past 5 years. The researcher has conducted extensive interviews with ASEZA and ADC members and leaders of Aqaba neighborhood groups. As part of a larger research project that involved interviews, surveys, and participant observations, the researcher attended community meetings to understand and prescribe opportunities to facilitate relationships between ASEZA and the community.

\section{Rhetoric and Public Relations Create Social Capital}

The NETs employ traditional public relations tactics to inform the community. They publicize information about meetings in the mosques, community centers, and health centers. The promotional materials invite all members of the neighborhood to a central location, usually a school or community center, for a meeting. The strategic messages are tailored to encourage women and youth to attend, and word of mouth makes neighborhood residents aware that the meetings are a valuable way to articulate their needs to ASEZA.

The meetings provide a glimpse into the ways in which culture shapes a fully functioning society. Jordanian culture conservatively articulates traditional roles for men and women. On the night of the public meeting, the national NGO Jordan River Foundation pitches a tent in the neighborhood and sets up entertainment activities for the small children outside of the tent. Neighborhood women are encouraged to bring their children. When they 
enter the tent the women are offered seats in circles with other women. Men sit with other men, and the youth (usually male) sit in one group together as well. Seats are organized into circles and in the middle of each grouping of chairs, there is butcher-block paper with a list of priorities for the neighborhood. Facilitators give each participant a certain number of stickers and ask them to place the stickers on the topic that they believe is most in need of improvement in the neighborhood.

These topics, such as roads, pest control, parks, and education, are issues that are within ASEZA's purview. They are services that ASEZA is tasked with providing to the community. But because of weak capacity, many of these services are inadequate or underdeveloped. Each person identifies his or her priorities within the group. The group members spend time talking about the topics adding personal anecdotes. Eventually, the individual priorities are tabulated to represent a group list, and then one member of each group is asked to report his or her group's priorities to the entire neighborhood. A JRF facilitator tabulates the group choices and publicly counts each time a priority is selected. At the end of the session, the neighborhood has voted for their priorities in a transparent, participatory manner that allows for discussion. Residents in Aqaba may not have a vote in electing their local government, but they now can vote to identify their neighborhood priorities. Here are the beginnings of community rhetoric and within the public relations structure of local and national government.

There are other ways that social capital is created in Aqaba. Once the priorities have been identified, the facilitator asks for individuals to volunteer to lead the neighborhood presentation of its priorities to ASEZA. The NET members already know that some people are interested in this role, but they want to provide all residents with the opportunity to take the next step in advocating for these improvements with ASEZA. At first, no one usually volunteers. Then, after a little encouragement from the JRF and CHF facilitators, nominations emerge. The ideal group should include both men and women. This group is now the neighborhood team that will present the neighborhood priorities to ASEZA. Here dialogue is struggling, but at least has a chance to develop. This group is also responsible for keeping the neighborhood informed of the progress of responsible parties charged with meeting the neighborhood requests.

\section{Creating Dialogic Systems in Organizations}

During the next week, the neighborhood group meets with ASEZA representatives to present their priorities. The ASEZA representative, usually a commissioner or a division head, is tasked with taking the neighborhood 
priorities to the commissioners and the appropriate directorates in ASEZA for action. The neighborhood representatives and the ASEZA representative agree to regularly scheduled meetings in the neighborhood to monitor the progress of the projects. These meetings are much smaller and allow for members of the NET to talk directly with the ASEZA representative. The ASEZA representative is supposed to go back to the organization after these meetings to report any problems with the project. The NET members and elected neighborhood members report back to the community on the progress. The back and forth of neighborhood input and subsequent ASEZA response continue until each project is completed.

Here the process can fail. Simple tasks such as paving streets, collecting trash, or eradicating pests may not be simple for an organization lacking sufficient capacity to do so. The neighborhood does not meet again to create priorities until the requests for improvements are complete. Three or 4 months might go by before the tasks are fulfilled. Those 3 or 4 months are a loss to the social capital of the neighborhood because there are no other mechanisms to bring people together. The projects do come to fruition and the ASEZA representatives, the elected members of the NET, and neighborhood meet for a formal celebration when the project is complete. The residents of Aqaba see firsthand that their agency has created a better place to live. The NETs schedule another neighborhood meeting and publicize it to the community through both mediated and face-to-face communication. The turnout is usually quite large in these meetings. Residents will remember the improvements that came with the last meeting. And ASEZA hopefully has created or increased its capacity to operate based on the input derived from its past projects. When the meeting starts, the social capital formation process begins again.

\section{Rhetoric and Public Relations' Contributions to a More Fully Functioning Aqaba}

The example of building dialogue in Aqaba illustrates how the organizational rhetoric of civil society actors can be extended through public relations activities. Rhetoric and public relations (as the enactment of rhetoric) are essential to building and sustaining a fully functioning society because they create various types of social capital. Rhetoric and public relations in Aqaba, whether by the local businesses, ASEZA, or the neighborhood activists, are valuable because they are resources that help all actors fulfill the requirements of a fully functioning society to manage uncertainty, ensure responsibility, pursue self-interest, cooperate, communicate, and advocate for choices. 
A fully functioning society is premised on various organizational, societal, and rhetorical conditions. Heath's image of a fully functioning society is based on relationships among organizations and groups. The relationships, sometimes adversarial and sometimes cooperative, create the opportunities for social capital that make the community better able to meet the needs of its members. Social capital emerges from a fully functioning society when organizations make good decisions and use their economic or symbolic power justly, organizational actions respond to publics' expectations, and collective advocacy creates enlightened self-interest with a desire to find intersections of interests.

\section{Concluding Thoughts}

Rhetorical discourse creates the shared images that lead to understanding and agreement. Discourse from a variety of rhetors shapes the physical and mental environments in which people live. Discourse allows individuals, groups, and organizations to articulate and evaluate ideas that form the basis of a civil society. If we accept public relations as the use of communication to negotiate relationships among groups (Botan, 1992) then we also should accept that any group could so engage to build or change relationships. The outcome of any communication and relationship-building activities is open to negotiation.

Rhetoric provides the discourse and the competing and shared images, whereas public relations provides the discourse process through which images are shared, negotiated, contested, and possibly resolved. Taylor (2009) has argued that meaning making and relationships enact civil society. The social capital that is created by shared meaning and relationships makes society a better place to live. Although dialogue is premised on an orientation to the other, there also needs to be an individual or organizational capacity to follow through on the dialogue. This case study shows the crucial link between having internal structures and processes in place to meet the needs of the external civil society groups. To make a community a better place to live, all civil society partners must be willing and able to advocate for their interests and then follow through on their commitments. Having said this, one can acknowledge that just as rhetoric can destroy and divide community, it is also important to discuss and recommend ways that organizational rhetoric can build community. Through discourse, individuals identify with others (and disassociate from others) and join short-lived or long-term relationships that will build the social capital of communities. 


\section{Declaration of Conflicting Interests}

The author declared no potential conflicts of interest with respect to the research, authorship, and/or publication of this article.

\section{Funding}

The author received no financial support for the research, authorship, and/or publication of this article.

\section{References}

Al-Anis, M. H. (2007). The Aqaba Special Economic Zone: A model for reform? Retrieved from http://www.menaar.org/index_files/Page2891.htm

Botan, C. (1992). International public relations: Critique and reformulation Public Relations Review, 18, 149-159.

Boulding, K. D. (1977). The image: Knowledge in life and society. Ann Arbor: The University of Michigan.

Bourdieu, P. (1986). The forms of capital. In J. G. Richardson (Ed.), Handbook of theory and research for the sociology of education (pp. 241-258). New York, NY: Greenwood.

Boyd, J., \& Stahley, M. B. (2008). Communitas/corporatas tensions in organizational rhetoric: Finding a balance in sports public relations. Journal of Public Relations Research, 20, 251-270.

Coleman, J. S. (1988). Social capital in the creation of human capital. American Journal of Sociology, 94, 95-120.

Granovetter, M. S. (1973). The strength of weak ties. American Journal of Sociology, $78,1360-1380$.

Heath, R. L. (1992). The wrangle in the marketplace: A rhetorical perspective of public relations. In E. L. Toth \& R. L. Heath, (Eds.), Rhetorical and critical approaches to public relations (pp. 17-36). Hillsdale, NJ: Lawrence Erlbaum.

Heath, R. L. (2006). Onward into more fog: Thoughts on public relations' research directions. Journal of Public Relations Research, 18, 93-114.

Ihlen, O. (2007). Building on Bourdieu: A sociological grasp of public relations. Public Relations Review, 33, 269-274.

Kardoosh, M. A. (2005). The Aqaba Special Economic Zone, Jordan: A case study of governance. Bonn, Germany: Center for Development Research.

Kennan, W. R., \& Hazelton, V. (2006). Internal public relations, social capital, and the role of effective organizational communication. In C. H. Botan \& V. Hazelton (Eds.), Public relations theory II (pp. 311-338). Mahwah, NJ: Lawrence Erlbaum.

Kent, M. L., \& Taylor, M. (2002). Toward a dialogic theory of public relations. Public Relations Review, 28, 21-37. 
Kruckeberg, D., \& Stark, K. (1988). Public relations and community: A reconstructed theory. New York, NY: Praeger.

Leeper, K. (1986). Public relations: Ethics and communitarianism. Public Relations Review, 22, 163-179.

Leeper, R. (2000). In search of a meta theory of public relations: An argument for communitarianism. In R. L. Heath (Ed.), Handbook of public relations (pp. 93-104). Thousand Oaks, CA: SAGE.

Lewis, L. (2005). The civil society sector: A review of critical issues and research agenda for organizational communication scholars. Management Communication Quarterly, 19, 238-267.

Nahapiet, J., \& Ghoshal, S. (1998). Social capital, intellectual capital, and the organizational advantage. The Academy of Management Review, 23, 242-266.

Pearson, R. (1989). A theory of public relations ethics. Unpublished doctoral dissertation, Ohio University, Athens.

Talal, B. B. (2004). Rethinking an NGO: Development, donors and civil society in Jordan. London: I. B. Tauris.

Taylor, M. (2009). Civil society as a rhetorical public relations process. In R. Heath, E. L. Toth, \& D. Waymer (Eds.), Rhetorical and critical approaches to public relations II (pp. 76-91). Mahwah, NJ: Lawrence Erlbaum.

\section{Bio}

Maureen Taylor (PhD, Purdue University) is professor and Gaylord Family Chair of Strategic Communication in the Gaylord College of Journalism and Mass Communication at the University of Oklahoma. Her research interest is in international public relations, nation-building and civil society campaigns, and new communication technologies. 